\title{
DERADIKALISASI BERBASIS NILAI-NILAI PESANTREN STUDI FENOMENOLOGIS DI TULUNGAGUNG
}

\author{
Ngainun Naim \\ Institut Agama Islam Negeri Tulungagung \\ Jl. Mayor Sujadi Timur 46, Tulungagung, 66221, Indonesia \\ E-mail:naimmas22@gmail.com
}

\begin{tabular}{l|l|l}
\hline Received: & Revised: & Approved: \\
14/03/2017 & $22 / 06 / 2017$ & $22 / 06 / 2017$ \\
\hline
\end{tabular}

\section{Abstrak}

Gerakan Islam radikal telah hadir dan melebarkan sayap organisasi di Tulungagung. Fenomena ini tampaknya belum mendapatkan respon memadai dari pihak pemerintah daerah. Padahal, eksistensi Islam radikal cukup membahayakan kehidupan sosial kemasyarakatan dalam jangka panjang. Oleh karena itu, diperlukan berbagai strategi untuk membendung persebaran ideologi dan gerakan Islam radikal. Artikel ini bertujuan untuk mengetahui respon para kiai Tulungagung terhadap Islam radikal dan strategi yang dilakukan untuk membendung penyebaran ideologi Islam radikal. Para kiai di Tulungagung memandang bahwa Islam radikal membahayakan bagi kehidupan masyarakat secara keseluruhan. Salah satu alasannya karena ideologi Islam radikal mengabsahkan kekerasan. Selain itu, karakteristik mereka yang eksklusif menjadikan eksistensinya sering menjadi masalah bagi masyarakat yang ada di sekitarnya. Pondok Pesantren merupakan salah satu institusi yang 
memiliki potensi besar untuk melakukan aktivitas deradikalisasi. Langkah yang ditempuh adalah dengan melakukan aktualisasi nilai-nilai pesantren. Aktualisasi nilai-nilai pesantren penting dilakukan karena dengan cara semacam ini diharapkan tumbuh pemahaman dan kesadaran secara luas terhadap keberadaan Islam radikal dan bahayanya bagi kehidupan. Data yang disajikan dalam kajian ini berasal dari wawancara dan observasi terhadap beberapa kiai di Tulungagung. Data yang terkumpul kemudian dianalisis dengan kerangka teori deradikalisasi. Penelitian ini menemukan bahwa para kiai di Tulungagung telah berusaha keras membendung arus Islam radikal ke dalam berbagai usaha deradikalisasi. Usaha para kiai tersebut penting dalam kerangka menghadirkan Islam moderat yang menghargai terhadap pluralitas di masyarakat.

Kata Kunci: Islam radikal, kiai, dan deradikalisasi.

\section{Abstract}

The radical Islamic movement has come and expanded its organization in Tulungagung. This phenomenon has seemingly got no adequate response from the local government yet. In fact, its existence has threatened the long term-social life. Therefore, it needs various strategies to stem the spread of radical Islamic ideology and movement. This article is intended to find out the responses of kyai (ulama, experts in Islam) in Tulungagung towards the radical Islam and strategies undertaken to stem the spread of radical Islamic ideology. The kyais in Tulungagung consider that the radical Islam endangers the life of society as a whole. One of the reason is that the ideology endorses violence. In addition, their exclusive characteristics make their existence be a problem for the surrounding people. Islamic boarding school (pondok pesantren) is then taken into account as an institution 
which has great potential for deradicalization activities. The step done is by actualizing the values of pesantren which is significant to establish broad understanding and awareness on the existence of radical Islam and its dangers for the life. The data presented in this study were collected through interviewing and doing observations to some kyais in Tulungagung. The collected data were subsequently analyzed by using the theorical framework of deradicalisation. The study reveals that kyais in Tulungagung have tried hard to stem the flow of radical Islam through various efforts of deradicalization which are essential to introduce a moderate Islam appreciating the values of plurality in society.

Keywords: radical Islam, kiai, and deradicalization.

\section{A. Pendahuluan}

Semenjak era reformasi, Islam di Indonesia mengalami dinamika yang menarik. Berbagai corak, karakter, dan varian Islam tumbuh secara pesat. Salah satu corak yang berkembang adalah apa yang disebut sebagai Islam radikal. Islam radikal sesungguhnya merupakan kelompok kecil, tetapi kiprah, aksi, dan perjuangan mereka cukup mewarnai dinamika kehidupan sosial politik di Indonesia. Karakteristik yang melekat kuat pada Islam radikal adalah eksklusif dan mengabsahkan penggunaan jalan kekerasan. Karena itulah, keberadaan kelompok Islam radikal memunculkan keresahan dalam skala luas. Apalagi eksistensi kelompok ini terus berkembang dari waktu ke waktu. ${ }^{1}$

1 Abu Rokhmad, "Radikalisme Islam dan Upaya Deradikalisasi Paham Radikal," Walisongo, Jurnal Penelitian Sosial Keagamaan 20, no. 1 (n.d.): 80-82; M. Zaki Mubarak, “Dari NII ke ISIS: Transformasi Ideologi dan Gerakan dalam Islam Radikal di Indonesia Kontemporer," Epistemê, Jurnal Pengembangan Ilmu Keislaman 10, no. 1 (Juni 2015): 79. 
Islam radikal sendiri sesungguhnya tidak tunggal. Ada banyak karakteristik dan varian pada kelompok Islam radikal. Realitas ini menunjukkan bahwa Islam radikal senantiasa tumbuh dan berkembang selaras dengan dinamika internal dan eksternal. Ada berbagai faktor yang berkait-kelindan dan mempengaruhi satu sama lain. Beberapa faktor yang bisa diidentifikasi, antara lain, kepemimpinan gerakan organisasi Islam radikal, watak rezim penguasa, dan pengaruh globalisasi. ${ }^{2}$

Secara lebih terperinci, Rahardjo mengidentifikasi beberapa faktor yang menjadi pendorong kian suburnya perkembangan Islam radikal di Indonesia. Pertama, pengaruh gerakan-gerakan transnasional. Kedua, terbukanya arus demokratisasi di era reformasi menjadikan euforia kelompok-kelompok Islam radikal. Ketiga, penegakan hukum di era demokratisasi jauh dari memuaskan sehingga memunculkan semangat untuk menegakkan syariat Islam. Dan keempat, kegagalan gerakan Islam rahmatan lil ãlamîn, yang toleran dan menghargai terhadap keanekaragaman. ${ }^{3}$

Fenomena Islam radikal bukan fenomena sederhana. Ia merupakan fenomena yang sangat kompleks. Aspek penting yang tidak bisa diabaikan, radikalisme keagamaam merupakan manifestasi dari persinggungan antara agama dan politik. Persinggungan ini berkaitan dengan dinamika dalam skala global hingga pada level lokal. Namun ia juga bertautan dengan kompleksitas relasi modernisasi dan globalisasi yang memberikan ruang bagi munculnya

2 Azyumardi Azra, Transformasi Politik Islam: Radikalisme, Khilafatisme dan Demokrasi (Jakarta: Kencana, 2016), 133.

3 M. Dawam Rahardjo, "Fanatisme dan Toleransi," in Berislam Secara Toleran, ed. oleh Irwan Masduqi (Bandung: Mizan, 2011), xxvii. 
identitas parokial dan ekspresi politik yang lekat dengan nuansa kekerasan. ${ }^{4}$

Islam radikal sekarang ini telah masuk ke wilayahwilayah yang sebelumnya tidak pernah diperhitungkan, termasuk ke Kabupaten Tulungagung. Mereka masuk melalui berbagai cara, seperti mendirikan organisasi, melakukan berbagai kegiatan lewat jalan pendidikan, hingga infiltrasi ideologi. Semangat mengembangkan organisasi dan ideologi sedemikian kuat pada para aktivis Islam radikal.

Sebagai bukti, pada akhir Maret 2015, Densus 88 menangkap seorang terduga anggota ISIS di Tulungagung. ${ }^{5}$ Sebelumnya, umat Islam Tulungagung sempat bergolak berkaitan dengan deklarasi Front Pembela Islam (FPI). FPI adalah organisasi Islam radikal yang eksistensinya menimbulkan banyak perdebatan karena aksi-aksinya yang sarat kekerasan. FPI merupakan sebuah organisasi yang diidentifikasi sebagai organisasi Islam radikal. ${ }^{6}$ Saat FPI Tulungagung dideklarasikan, terdapat penolakan massa secara luas.7 Selain itu, beberapa organisasi Islam radikal lain juga mengembangkan sayap di Tulungagung.

Fenomena Islam radikal yang kini semakin menyebar tidak bisa dibiarkan begitu saja. Dibutuhkan respon kreatif dan sistematis agar persebaran Islam radikal tidak semakin mengakar kuat dalam masyarakat. Sebab, masa depan

4 Noorhaidi Hasan, "Laskah Jihad: Islam, Militansi, dan Pencarian Identitas di Indonesia Pasca-Orde Baru," trans. oleh Hairus Salim (Jakarta: LP3ES, 2008), vii-viii.

5 "Polisi Tangkap Orang yang Diduga Anggota ISIS di Tulungagung," 28 Februari 2016, http://www.antaranews.com.

${ }^{6}$ Eric Hiariej, "Aksi dan Identitas Kolektif Gerakan Islam Radikal di Indonesia," JSP, Jurnal Ilmu Sosial dan Ilmu Politik 4, no. 2 (November 2010): 132.

7 "Masyarakat Tulungagung Demo Tolak FPI," diakses 28 Februari 2016, http://news.okezone.com. 
Indonesia yang damai hanya mungkin terbangun jika pemahaman agama yang berkembang di masyarakat adalah pemahaman agama moderat.

Pada titik inilah, pondok pesantren menjadi salah satu institusi yang diharapkan memberikan kontribusi penting. Pondok pesantren telah hadir sepanjang sejarah Islam Indonesia. Kontribusinya terhadap terbangunnya Islam moderat sudah teruji oleh waktu. ${ }^{8}$ Karena itulah, di tengah tantangan semakin menyebarnya Islam radikal, kiprah pondok pesantren dituntut untuk semakin terlihat nyata.

Eksistensi pondok pesantren dipengaruhi oleh kiainya. Jika kiai pondok pesantren memiliki perspektif konstruktif tentang Islam dalam perspektif sosial kemasyarakatan, maka akan ada implikasi nyata terhadap terbentuknya wajah Islam yang lebih membumi. Karena itulah, posisi kiai sangat menentukan terhadap terbentuknya wajah Islam di pondok pesantren dan masyarakat sekitarnya.

Ada tiga masalah yang dibahas pada tulisan ini, yaitu pandangan kiai Tulungagung terhadap Islam radikal; nilainilai pesantren yang sejalan dengan strategi deradikalisasi, dan strategi yang diterapkan para kiai dalam menghadapi Islam radikal.

Sebagai penelitian lapangan dengan jenis penelitian kualitatif, data primer kajian ini diperoleh dari wawancara bebas dengan beberapa kiai pondok pesantren di Tulungagung. Ada empat orang kiai yang dipilih. Mereka dipilih berdasarkan representasi besarnya pesantren dan lokasi, yaitu K.H. Muhson Hamdani dari Pondok Pesantren Sunan Kalijaga Ngunut, K.H. Muh. Nurul Huda dari Pondok Pesantren Panggung, K.H. Bagus Ahmadi dari Pondok Pesantren MIA Moyoketen, dan K.H. Hadi M.

8 Syamsun Ni'am, "Pesantren: The Miniature of Moderate Islam in Indonesia," Indonesian Journal of Islam and Muslim Societies 5, no. 1 (Juni 2015): 124. 
Mahfudh dari Pondok Pesantren Al-Hikmah Kalangbret. Sementara data skunder digunakan untuk melengkapi isi kajian yang diperoleh dari data cetak maupun elektronik. Data-data yang diperoleh dari hasil wawancara dan dari sumber yang lainnya kemudian direduksi untuk mendapatkan data yang sesuai dengan fokus kajian. Analisis dilakukan dalam kerangka teori deradikalisasi agama.

\section{B. Radikalisme Islam di Tulungagung}

Islam radikal terbukti telah hadir dan menjalankan aksinya di berbagai wilayah di Indonesia, termasuk di Tulungagung. Sebagai wilayah pinggiran yang jauh dari hiruk-pikuk kehidupan sosial politik nasional, kehadiran kelompok Islam radikal memantik perdebatan di kalangan masyarakat.

Eksistensi kelompok Islam radikal di Tulungagung mendapatkan berbagai macam respon. Salah satunya adalah usaha dari berbagai elemen masyarakat untuk sosialisasi terhadap bahaya Islam radikal sekaligus antisipasi berbagai kemungkinan penyebarannya dalam skala luas. Usaha ini dilakukan karena ekses negatif Islam radikal yang membahayakan tatanan yang telah ada. ${ }^{9}$

Para kiai di Tulungagung melihat bahwa Islam radikal merupakan jenis Islam yang mengganggu terhadap ketenteraman kehidupan masyarakat. Melihat karakteristik, kiprah, dan aksi yang dilakukan, eksistensi Islam radikal jelas ditolak oleh kalangan kiai pesantren. Hal ini disebabkan karena keberadaannya yang dianggap

9 "Pemuda di Tengah Gerakan Radikalisme Islam dan ISIS," diakses 28 April 2017, www.tribratanewstulungagung.net/2015/06/polrestulungagung-pemuda-ditengah-gerakan-radikalisme-islam-danisis/. 
berseberangan dengan pola Islam yang selama ini telah mengakar kuat di masyarakat. Penolakan ini bisa dipahami mengingat kelompok Islam radikal tidak jarang melakukan berbagai aksi yang ekstrim. Kondisi ini terjadi karena;

Radical Islam refers to those Islamic movements that seek dramatic change in society and the state. The comprehensive implementation of Islamic law and the upholding of "Islamic norms", however defined, are central elements in the thinking of most radical groups. Radical Muslims tend to have a literal interpretation of the Qur'an, especially those sections relating to social relations, religious behavior and the punishment of crimes, and they also seek to adhere closely to the perceived normative model based on the example of the Prophet Muhammad.10

Menurut K.H. Hadi M. Mahfudh, Pengasuh Pondok Pesantren Al-Hikmah Mlati Tulungagung yang juga menjadi Ketua Umum Majelis Ulama Indonesia Kabupaten Tulungagung, Islam radikal di Tulungagung bukan hanya wacana, tetapi betul-betul ada. Keberadaan kelompok Islam radikal juga jelas-jelas diketahui masyarakat secara luas. Kiai Hadi menyebut bukti tentang spanduk sebuah organisasi Islam yang jelas mengkampanyekan negara khilafah, bukan negara Pancasila. "Itu menjadi pintu bagi persebaran radikalisme". 11

Islam radikal dipahami sebagai kelompok yang memiliki corak keberagamaan ekstrim, tidak toleran, dan mengabsahkan penggunaan jalan kekerasan. Kelompok ini

${ }^{10}$ Greg Fealy, Voices of Islam in Southeast Asia: A Contemporary Sourcebook, ed. oleh Virginia Hooker (Singapore: ISEAS, 2006), 4.

11 "MUI Tuding Pemerintah Lembek Hadapi Radikalisme," diakses 18 Januari 2016, http:/ / nasional.sindonews.com pada ... 
memiliki fanatisme berlebihan. "Mereka juga bersikap sangat keras, bahkan berlebihan. Orang yang meninggalkan perkara sunnah saja mereka nilai kafir."12 Implikasi dari cara pandang semacam ini adalah intoleransi. Ukuran kebenaran hanyalah apa yang mereka rumuskan. Rumusan kelompok yang lain dianggap sebagai salah.

Selain itu, kelompok Islam radikal memiliki komitmen kelompok yang sangat kokoh. Mereka juga berusaha keras untuk melakukan rekruitmen anggota secara intensif. Salah satu elemen masyarakat yang sangat potensial dan rentan dengan radikalisasi adalah remaja (kaum muda) yang dikatakan sebagai youth berumur 16-19 tahun, setingkat SMA di Indonesia. ${ }^{13}$ Pilihan terhadap anak-anak muda tampaknya didasarkan kepada pemahaman bahwa, "kaum muda dinilai sebagai agen penting dalam proses peradaban, khususnya karena melalui kaum mudalah unsur-unsur baru dapat dengan mudah dimasukkan dalam suatu masyarakat."14

Oleh karena itu, para kiai pesantren memandang keberadaan Islam radikal harus mendapatkan perhatian seluruh pihak, terutama dari pemerintah. Sebab jika dibiarkan, eksistensi mereka bisa membahayakan kehidupan sosial politik secara keseluruhan. Hal ini disebabkan karena Islam radikal itu tidak muncul begitu saja. Mereka menjalankan ajaran agama secara keras bukannya tanpa motif. Mereka memiliki motif dan tujuan tertentu.

12 Wawancara dengan K.H. Bagus Ahmadi, 1 Maret 2016, Pengasuh Pondok Pesantren MIA, Moyoketen Tulungagung.

13 Zuly Qodir, Radikalisme Agama di Indonesia (Yogyakarta: Pustaka Pelajar, 2014), 75.

14 Irwan Abdullah, Konstruksi dan Reproduksi Kebudayaan, 3 ed. (Yogyakarta: Pustaka Pelajar, 2010), 181. 
Kelompok Islam radikal memiliki beberapa karakteristik. Pertama, mereka melakukan radikalisasi sebagai respons terhadap dinamika kehidupan yang tengah berlangsung. Bentuk responnya berupa evaluasi, penolakan, atau bahkan perlawanan, tergantung kepada berbagai aspek yang mempengaruhi. Masalah yang direspon adalah yang tidak sesuai dengan keyakinan mereka, mulai dari ide, asumsi, lembaga, atau nilai-nilai kehidupan.

Kedua, penolakan bukan berarti menjadi titik akhir. Radikalisasi melanjutkan penolakan itu pada upaya secara terus-menerus untuk mengganti tatanan yang dikritik atau ditolak dengan tatanan baru yang sesuai dengan Islam radikal. Hal ini secara implisit menunjukkan bahwa di dalam radikalisasi terkandung sebuah program atau pandangan dunia tersendiri.

Ketiga, keyakinan yang sangat kokoh bahwa ideologi mereka yang paling benar dan ideologi yang lain salah. Demi membela dan memaksakan keyakinan ini, mereka akan melakukan apapun, termasuk jalan kekerasan. ${ }^{15}$

Justru karena radikalisasi yang semacam inilah maka diperlukan respon yang kreatif dan terus-menerus. Islam radikal akan terus mengembangkan ideologi dan institusinya sampai tujuan utama mereka tercapai, yaitu mengganti sistem yang ada. Penggantian sistem ini dapat tercapai tatkala berbagai instrumen dalam kehidupan sosial kemasyarakat mendukung. Dalam kerangka inilah maka berbagai cara untuk mewujudkan tujuan dilakukan. Pada titik inilah kegelisahan para kiai terhadap fenomena Islam radikal menemukan titik signifikansinya.

15 Khoirul Faizin, "Fundamentalisme dan Gerakan Radikal Islam Kontemporer di Indonesia," Edu-Islamika 5, no. 2 (September 2013): 348. 


\section{Deradikalisasi dari Pesantren}

Berbagai upaya untuk mencegah tumbuh dan berkembangnya kelompok radikal telah dilakukan. Namun demikian ternyata sampai sekarang ini kita belum memiliki strategi andal menangkal kelompok radikal. ${ }^{16}$ Implikasinya, kelompok radikal dalam berbagai variannya terus saja menyebarkan sayapnya ke berbagai lini kehidupan. Mereka terus saja mengembangkan dirinya tanpa bisa dibendung. Faktor sosial politik yang terbuka membuat kesempatan tersebut semakin terbuka lebar. Meminjam kerangka Torrow, kelompok radikal Islam di Indonesia bisa berkembang sedemikian cepat dan luas karena realitas politik yang semakin terbuka. Selain itu, di dalam lingkaran kelompok radikal juga memiliki dukungan sumberdaya yang memadai. Sumberdaya tersebut berhasil dimobilisasi untuk mewujudkan tujuan organisasi. ${ }^{17}$

Dalam kerangka mencegah persebaran Islam radikal, satu langkah yang penting untuk dilakukan adalah deradikalisasi. Deradikalisasi memiliki makna dan cakupan yang luas. Dalam konteks tulisan ini, definisi deradikalisasi mengikuti rumusan Insani dan Naispospos yang mengartikal deradikalisasi sebagai deteksi secara dini, menangkal sejak awal, dan menyasar berbagai lapisan potensial dengan beragam bentuk dan varian yang relevan bagi masing-masing kelompok yang menjadi sasaran. ${ }^{18}$

16 Adjie Suradji, “Ancaman Teroris Generasi Baru,” Kompas, 3 Februari 2016, 6.

17 Sidney Tarrow, Power in Movement: Social Movement, Collective Action and Politics (Cambridge: Cambridge University Press, 1995), 1-2.

18 Ismail Hasani, Dari Radikalisme Menuju Terorisme: Studi Relasi dan Transformasi Organisasi Islam Radikal di Jawa Tengah $\mathcal{E}$ D.I. Yogyakarta, ed. oleh Bonar Tigor Naispospos (last) (Yogyakarta: Pustaka Masyarakat Setara, 2012), 191. 
Pilihan terhadap strategi deradikalisasi didasarkan kepada pemikiran bahwa upaya pencegahan gerakan radikal melalui jalur represif-formalistik pada realitasnya tidak sepenuhnya efektif. Pola-pola penanganan represifformalistik hanya mampu menghentikan sementara arus pergerakan radikalis. Selain itu, pola semacam itu juga memiliki peluang yang besar bagi tumbuhnya arus sejenis ketika kondisi memungkinkan. Jalan kekerasan yang ditempuh hanya akan memunculkan kekerasan jenis lain di waktu yang berbeda.

Namun demikian, program deradikalisasi sesungguhnya bukan program sederhana. Ada berbagai kerumitan, hambatan, dan kompleksitas persoalan dalam tataran implementasinya. Pokok persoalannya terletak pada substansi ajaran agama yang menjadi medan perebutan antara kelompok radikalis dengan kelompok deradikalis. $\mathrm{Hal}$ ini wajar mengingat gerakan radikalis dan deradikalisasi sesungguhnya memiliki obyek dasar yang sama. Keduanya berjuang melalui berbagai upaya untuk memperbutkan agama agar selaras dengan kepentingan mereka.

Aspek mendasar lainnya adalah deradikalisasi tidak selalu mudah pada tataran implementasi. Kerumitan implementasi gerakan deradikalisasi semakin terasa ketika objeknya adalah mereka yang telah mengalami radikalisasi pemahaman agama. Mereka yang teradikalisasi cenderung menjadi sosok yang intoleran. Jika tidak mendapatkan penanganan kondusif dalam kerangka deradikalisasi, tidak tertutup kemungkinan mereka dengan cepat dapat menjadi teroris. ${ }^{19}$ Kondisinya berbeda dengan mereka yang belum

19 M. Amin Abdullah, "Islam dan Keindonesiaan," in Kontroversi Khilafah: Islam, Negara, dan Pancasila, ed. oleh Komaruddin Hidayat (Bandung: Mizan, 2014), 207. 
pernah teradikalisasi. Mereka lebih mudah memahami dan menyerap spirit keberagamaan yang non-radikal.

Problem lainnya adalah program deradikalisasi yang ada selama ini dijalankan tidak sistematis, sporadis, dan tidak berkelanjutan. Implikasinya, program deradikalisasi tidak mampu mencegah penyebaran gerakan Islam radikal secara lebih intensif. 20 Padahal, kelompok Islam radikal terus melebarkan sayapnya dengan berbagai cara tanpa terhenti. Pada titik inilah gerakan deradikalisasi seharusnya dilakukan secara intensif, berkelanjutan, dan melibatkan berbagai unsur secara komprehensif.

Deradikalisasi tidak bisa mengandalkan kepada satu institusi semata. Semua elemen yang memiliki peranan harus menjalankan tugas deradikalisasi ini secara intensif. Dengan demikian, deradikalisasi menjadi gerakan bersama yang melibatkan berbagai stakeholders dalam kerangka yang sistematis. Salah satu institusi yang bisa menjalankan peran strategis adalah pendidikan. ${ }^{21}$

Secara praktis, Arifin menawarkan dua langkah strategis yang dapat dilakukan oleh institusi pendidikan, termasuk pondok pesantren, dalam kerangka deradikalisasi. Langkah pertama adalah melakukan deteksi dini (early warning) terhadap pergerakan paham radikal, baik yang melalui proses dari atas ke bawah (top-down process) yang dilakukan oleh pihak luar, maupun yang dilakukan dari bawah ke atas (bottom-up process) yakni individu sendiri yang mengekplorasi paham radikal melalui berbagai sumber sehingga dirinya terinfiltrasi. Mengenal secara dini terhadap perilaku yang terinfiltrasi

20 Zuly Qodir, Radikalisme Agama di Indonesia (Yogyakarta: Pustaka Pelajar, n.d.), 112-114.

${ }^{21}$ Uraian secara menarik terhadap persoalan ini bisa dibaca di Syaiful Arif, Deradikalisasi Islam: Paradigma dan Strategi Islam Kultural (Depok: Koekosan, 2010), 107-34. 
oleh paham radikal sebenarnya relatif mudah. Hal ini dapat dilakukan dengan mengamati perilaku sehari-hari, membandingkannya dengan perilaku sebelumnya dan mencermati ada atau tidaknya perubahan dari perilaku mereka.

Deteksi secara dini menuntut adanya suatu pola hubungan yang memungkinkan pihak pengajar memiliki kepekaan terhadap perubahan paham keagamaan murid dan teman. Di lingkungan pondok pesantren, pola hubungan semacam ini tentu bukan persoalan yang rumit karena ustad memiliki kedekatan dengan para santrinya. Aspek yang seharusnya ditumbuhkan adalah kepekaan. Tanpa kepekaan, realitas perubahan dalam diri individu tidak akan terdeteksi oleh orang lain.

Perspektif psikologi sosial mengenal adanya dua pola interaksi. Pertama, hubungan pertukaran (exchange relationship). Hubungan semacam ini lebih banyak didasarkan pada kalkulasi-kalkulasi keterpenuhan kepentingan antar-kedua belah pihak. Kedua, hubungan komunal (communal relationship). Dalam lingkungan pendidikan, pola hubungan seperti ini perlu dikembangkan karena keterikatan antar-individu dalam suatu kelompok lebih didasarkan pada kasih sayang, kesetaraan, keadilan, dan perasaan ke-kita-an. Dalam kerangka deteksi dini, pola yang penting untuk dikembangkan adalah pola hubungan komunal. Pola hubungan komunal memungkinkan untuk memberikan respons persuasif terhadap individu yang terinfiltrasi paham radikal sehingga bisa dikembalikan kepada paham moderat.

Langkah kedua yang perlu dilakukan oleh institusi pendidikan dalam rangka deradikalisasi adalah dengan mengembangkan suatu model pendidikan yang dapat mencegah terjadinya infiltrasi paham radikal. Model ini perlu mengacu pada suatu desain utuh yang memuat: kerangka pandang yang mendasar (philosophical foundation) 
terhadap Islam; materi; model pembelajaran; serta lingkungan yang dapat menumbuhkan pengetahuan dan sikap pengakuan, toleran, dan koperatif terhadap pihak yang berbeda baik karena alasan agama, paham keagamaan, budaya, dan lain sebagainya. ${ }^{22}$

Strategi deradikalisasi seyogyanya dilakukan secara intensif agar membawa hasil yang lebih optimal. Keberhasilan strategi deradikalisasi akan berimplikasi pada tidak menyebarnya ideologi Islam radikal. Islam radikal yang eksklusif dan tidak menghargai terhadap keanekaragaman membuat wajah Islam Indonesia kurang ramah dan tidak toleran. Pada titik inilah deradikalisasi seharusnya dilakukan oleh seluruh instrumen masyarakat.

Dunia pesantren sesungguhnya memiliki potensi yang sangat besar untuk menjalankan tugas deradikalisasi. Sejarah panjang eksistensi dan kiprah pesantren menunjukkan bahwa radikalisasi sesungguhnya merupakan sesuatu yang jauh dari komunitas pesantren. Karena itu ketika ada wacana yang menyebutkan bahwa para pelaku kelompok Islam radikal tidak sedikit yang terdidik di dunia pesantren, maka wacana semacam itu jelas-jelas merugikan pesantren. ${ }^{23}$ "Pesantren jauh dari ajaran radikal". ${ }^{24}$

Namun, demikian perkembangan kontemporer menunjukkan bahwa para pelaku Islam radikal memang

22 Syamsul Arifin, "Multikulturalisme dalam Skema Deradikalisasi Paham dan Gerakan Keagamaan Radikal di Indonesia," Makalah AICIS XIV Samarinda, 21 November 2014, 2931.

23 Nuhrison M. Nuh, ed., Peranan Pesantren dalam Mengembangkan Budaya Damai (Jakarta: Badan Litbang dan Diklat Kementerian Agama, 2010), 3.

${ }^{24}$ Wawancara dengan K.H. Muhson Hamdani, 27 Februari 2016, Pengasuh Pondok Pesantren Sunan Kalijaga Ngunut Tulungagung. 
ada yang lulusan pesantren. Relasi pesantren dengan radikalisme, khususnya berkaitan dengan tuduhan bahwa pelaku radikalisme adalah lulusan pesantren, tampaknya berkaitan dengan dua hal. Pertama, adanya beberapa pesantren yang mengambil pola pendidikan impor dari negara yang menjadi basis Islam radikal. Kedua, cara pandang keislaman pesantren-pesantren semacam ini tekstualis-skripturalis. Mereka banyak merujuk kepada buku-buku karya para pemikir yang berhaluan keras seperti Sayyid Qutb dan Hassan Al-Bana.25 Salah satu pesantren yang masuk kategori ini adalah Pesantren Ngruki Solo. ${ }^{26}$ Namun demikian, pesantren jenis ini jumlahnya minoritas. ${ }^{27}$ Pesantren yang tipenya semacam ini biasanya bercorak eksklusif sehingga tidak memiliki kontribusi positif bagi perkembangan kemajuan masyarakat. ${ }^{28}$

Berangkat dari fenomena yang semacam ini maka pesantren sesungguhnya tengah menghadapi tantangan yang serius. Dinamika kehidupan di luar telah berkembang sangat pesat. Pada kondisi yang semacam itu, dunia pesantren seharusnya mampu memberikan kontribusinya agar perkembangan yang ada tetap sejalan dengan nilainilai ajaran Islam sebagaimana pemahaman kalangan pesantren. Sebab jika pemahaman Islam yang dikembangkan kelompok Islam radikal yang diserap masyarakat maka akan banyak efek negatifnya dalam kerangka harmonisasi sosial.

25 Nuh, Peranan Pesantren dalam Mengembangkan Budaya Damai, 3.

26 Badrus Sholeh, Budaya Damai dalam Komunitas Pesantren (Jakarta: LP3ES, 2007), xxviii.

27 Wawancara dengan K.H. Bagus Ahmadi.

28 Wawancara dengan K.H. Muh. Nurul Huda, 2 Maret 2016, Pengasuh Pondok Pesantren Panggung Tulungagung. 
Ajaran Islam radikal yang eksklusif dan intoleran membahayakan harmoni sosial. Pada titik inilah, pondok pesantren seharusnya menjalankan perannya secara lebih optimal. Langkah mendasar yang penting dilakukan adalah aktualisasi nilai-nilai pesantren. Aktualisasi ini dilakukan dalam kerangka deradikalisasi. Pesantren sesungguhnya memiliki banyak nilai yang sarat dengan kearifan. Nilainilai ini penting untuk diaktualisasikan dalam kerangka pijakan dalam perilaku hidup para santri dan masyarakat yang ada di lingkungan pesantren.

Nilai pertama sebagai strategi deradikalisasi yang ada di pesantren adalah seluruh kehidupan ini diyakini sebagai ibadah. Hal ini bermakna bahwa apapun yang dilakukan harus diniati sebagai ibadah. ${ }^{29}$ Nilai dasar ini berfungsi secara operasional dalam sinaran petunjuk kiai. Kiai biasanya menegaskan mengenai substansi ibadah dalam seluruh laku hidup santri dan masyarakat yang ada di sekitarnya.

Nilai kedua yang mendasari kehidupan pesantren adalah Ahlissunnah Wa al-Jamaah atau Aswaja. Islam Aswaja didefinisikan sebagai, "ajaran (wahyu Allah Swt) yang disampaikan Nabi Muhammad kepada sahabatsahabat-Nya dan beliau amalkan serta diamalkan oleh sahabat-sahabat-Nya."30

Paradigma pemikiran Aswaja bertumpu pada sumber ajaran Islam; Al-Quran, Al-Sunnah, Al-Ijmak, dan Qiyas. Sementara pada tataran praktik, umat Islam yang menganut Aswaja mengikuti produk pemikiran ulama di masa lalu. Ada tiga pilar inti yang menandai karakteristik

29 Bachtiar Effendy, "Nilai Kaum Santri," in Pergulatan Dunia Pesantren, ed. oleh M. Dawam Rahardjo (Jakarta: P3M, 1985), 49.

30 Masyhudi Muchtar, dkk., Aswaja An-Nahdliyah, Ajaran Ahlussunnah wa Al-Jama'ah yang Berlaku di Lingkungan Nahdlatul Ulama (Surabaya: LTN, 2007), 3. 
Aswaja, yaitu mengikuti faham Al-Asy'ari dan Al-Maturidi dalam bidang teologi, mengikuti salah satu dari empat imam mazhab (Hanafi, Maliki, Syafi'i, dan Hanbali) dalam bidang fikih, dan mengikuti Imam Junaid Al-Baghdadi dan Imam Al-Ghazali dalam bidang tasawuf. ${ }^{31}$

Selain itu Aswaja juga memiliki nilai-nilai yang menarik. Nilai-nilai tersebut adalah; nilai pertama adalah tawasuth (moderat). Menurut Kamus Besar Bahasa Indonesia, moderat memiliki dua arti, yaitu; (1) selalu menghindarkan perilaku atau pengungkapan yang ekstrem; berkecenderungan ke arah dimensi atau jalan tengah. ${ }^{32}$ Pemikiran moderat penting artinya karena dapat direkonstruksi untuk menjadi spirit perdamaian. Moderat menjadi modal penting untuk mengakomodasi berbagai kepentingan yang ada dan mencari solusi terbaik atas pertentangan yang terjadi.

Kedua, tawâzun (berimbang). Berimbang yang dimaksudkan dalam konteks ini adalah sikap berimbang dan harmonis dalam mengintegrasikan dan menyinergikan dailil-dalil untuk menghasilkan sebuah keputusan yang bijak. Tawâzun (berimbang) ini merupakan manifestasi dari sikap keberagamaan yang menghindari sikap ekstrim. Kelompok radikal disebut sebagai kelompok ekstrim karena kurang menghargai terhadap perbedaan pendapat dan tidak mengakomodasi kekayaan khazanah kehidupan.

Ketiga, toleransi (tasamuh) yang sangat besar terhadap pluralisme pikiran. Berbagai pikiran yang tumbuh dalam masyarakat Muslim mendapatkan pengakuan yang apresiatif. Keterbukaan yang demikian lebar untuk menerima berbagai pendapat menjadikan Aswaja memiliki

31 M. Masyhur Amin, NU dan Ijtihad Politik Kenegaraannya (Yogyakarta: Al-Amin Press, 1996), 80-85.

32 Departemen Pendidikan dan Kebudayaan, Kamus Besar Bahasa Indonesia, 3 ed. (Jakarta: Balai Pustaka, 1990), 589. 
kemampuan untuk meredam berbagai konflik internal umat Islam. Corak ini sangat tampak dalam wacana pemikiran hukum Islam. Wacana hukum Islam oleh banyak ahli dinilai sebagai wacana pemikiran keislaman yang paling realistik dan paling banyak menyentuh aspek relasi sosial. Dalam diskursus sosial budaya, Aswaja banyak melakukan toleransi terhadap tradisi-tradisi yang telah berkembang di masyaraka, tanpa melibatkan diri dalam substansinya, bahkan tetap berusaha untuk mengarahkannya. Formalisme dalam aspek-aspek kebudayaan dalam Aswaja tidaklah memiliki signifikansi yang kuat. Sikap toleran Aswaja telah memberikan makna khusus dalam hubungannya dengan dimensi kemanusiaan yang luas. ${ }^{33}$

Pada tataran praktis, signifikansi Aswaja tidak boleh hanya berhenti sebatas wacana. "Para santri diajarkan secara mendalam tentang Aswaja, mulai dari sejarah, paham, tokoh, dan berbagai hal lain yang terkait," jelas Kiai Bagus Ahmadi. ${ }^{34}$ Cara pengajarannya tidak hanya dilakukan di pondok pesantren saja, tetapi juga melalui berbagai kegiatan pengkajian secara intensif.

"Saya Direktur Aswaja Centre Tulungagung. Salah satu programnya adalah pendalaman materi secara intensif dalam bentuk pelatihan. Pelatihannya dilaksanakan berdasarkan kesepakatan yang telah ditentukan. Intinya adalah bagaimana Aswaja bisa dipahami secara

33 Husein Muhammad, "Memahami Sejarah Ahlus Sunnah Waljamaah Yang Toleran dan Anti Ekstrem," in Kontroversi Aswaja, Aula Perdebatan dan Reinterpretasi, ed. oleh Imam Baehaqi (Yogyakarta: LKiS, 2000), 37-41.

${ }^{34}$ Wawancara dengan K.H. Bagus Ahmadi, wawancara. 
intensif oleh para santri dan masyarakat Islam secara luas." 35

Aktivitas keseharian di pesantren yang sarat dengan berbagai ibadah sesungguhnya merupakan aplikasi lain dari deradikalisasi. Ini juga merupakan nilai ketiga dari strategi deradikalisasi. "Kegiatan harian di pesantren dalam bentuk amaliah shalawat, doa bersama, ziarah kubur dan sejenisnya adalah formula ampuh deradikalisasi." 36 Melalui aktivitas ibadah tersebut diharapkan tumbuh pemahaman dan kesadaran untuk mengedepankan penghargaan terhadap keragaman.

Strategi keempat yang bisa dilakukan adalah memahamkan para santri tentang Islam radikal. Strategi ini dilakukan melalui berbagai media. Pertemuan rutin setiap malam jumat yang dihadiri oleh seluruh santri adalah media yang tepat untuk menjelaskan tentang Islam damai sekaligus menjelaskan efek kehadiran Islam radikal.

Kelompok Islam radikal terus berusaha melakukan infiltrasi ke lembaga pendidikan Islam. Lembaga pendidikan yang menjadi tempat para santri belajar pun menjadi sasasaran. Karena itulah para kiai berusaha menanamkan pemahaman tentang Islam damai.

Fenomena Islam radikal tidak bisa dibiarkan. Harus dilakukan berbagai upaya secara intensif dengan melibatkan berbagai unsur yang ada. Aspek ini penting dilakukan karena ada kecenderungan perlawanan terhadap kelompok Islam radikal sifatnya reaktif dan sporadis. Respon baru diberikan ketika ada ekses dari aktivitas kelompok Islam radikal. Jika tidak ada maka Islam radikal seolah tidak menjadi topik perhatian.Pada kondisi yang

${ }^{35}$ Wawancara dengan K.H. Muhson Hamdani, 2 Maret 2016.

36 Wawancara dengan K.H. Muh. Nurul Huda, 19 Februari 2016. 
semacam inilah diperlukan pemahaman dan kesadaran bersama mengenai langkah deradikalisasi yang melibatkan seluruh komponen masyarakat. Perlu dilakukan berbagai upaya agar nilai-nilai etis yang menyangkut hakikat agama yang merupakan sumber nilai dalam pembentukan blue print bagi praktik kehidupan kurang berpengaruh. ${ }^{37}$

Islam radikal di Tulungagung telah memunculkan berbagai tanggapan, khususnya dari kalangan kiai. Upaya deradikalisasi kalangan kiai menjadi menarik ditinjau dari perspektif responsif terhadap dinamika eksternal yang kompleks. Melalui berbagai upaya diharapkan Islam radikal tidak semakin menancapkan saya pengaruhnya terhadap masyarakat.

\section{Simpulan}

Berdasarkan penjelasan di atas maka dapat disimpulkan bahwa para kiai Tulungagung memandang Islam radikal sebagai ancaman. Oleh karena itu, diperlukan berbagai langkah untuk antisipasi persebaran ideologi dan organisasi Islam radikal. Semua pihak, mulai dari pemerintah hingga kiai pesantren, harus bersatu padu dalam menjalankan deradikalisasi.

Dunia pesantren memiliki berbagai nilai yang aktual untuk deradikalisasi. Nilai-nilai pesantren penting untuk diaktualisasikan secara lebih intensif agar memberikan kontribusi nyata pada tumbuhnya Islam moderat. Nilainilai tersebut adalah seluruh dimensi kehidupan merupakan ibadah, Aswaja, aktivitas ritual yang merupakan aplikasi Aswaja, dan memahamkan para santri tentang Islam radikal. Melalui usaha-usaha semacam inilah diharapkan Islam radikal tidak menyebar secara luas di dalam masyarakat[.]

${ }^{37}$ Abdullah, Konstruksi dan Reproduksi Kebudayaan, 119. 


\section{REFERENSI}

Abdullah, Irwan. Konstruksi dan Reproduksi Kebudayaan. 3 ed. Yogyakarta: Pustaka Pelajar, 2010.

Abdullah, M. Amin. "Islam dan Keindonesiaan." In

Kontroversi Khilafah: Islam, Negara, dan Pancasila, diedit

oleh Komaruddin Hidayat. Bandung: Mizan, 2014.

Amin, M. Masyhur. NU dan Ijtihad Politik Kenegaraannya.

Yogyakarta: Al-Amin Press, 1996.

Arif, Syaiful. Deradikalisasi Islam: Paradigma dan Strategi

Islam Kultural. Depok: Koekosan, 2010.

Arifin, Syamsul. "Multikulturalisme dalam Skema

Deradikalisasi Paham dan Gerakan Keagamaan

Radikal di Indonesia." Makalah AICIS XIV Samarinda, 21

November 2014.

Azra, Azyumardi. Transformasi Politik Islam: Radikalisme, Khilafatisme dan Demokrasi. Jakarta: Kencana, 2016.

Departemen Pendidikan dan Kebudayaan. Kamus Besar Bahasa Indonesia. 3 ed. Jakarta: Balai Pustaka, 1990.

Effendy, Bachtiar. "Nilai Kaum Santri." In Pergulatan Dunia

Pesantren, diedit oleh M. Dawam Rahardjo. Jakarta: P3M, 1985.

Faizin, Khoirul. "Fundamentalisme dan Gerakan Radikal

Islam Kontemporer di Indonesia." Edu-Islamika 5, no. 2 (September 2013).

Fealy, Greg. Voices of Islam in Southeast Asia: A Contemporary Sourcebook. Diedit oleh Virginia Hooker. Singapore: ISEAS, 2006.

Hasan, Noorhaidi. "Laskah Jihad: Islam, Militansi, dan Pencarian Identitas di Indonesia Pasca-Orde Baru." diterjemahkan oleh Hairus Salim. Jakarta: LP3ES, 2008.

Hasani, Ismail. Dari Radikalisme Menuju Terorisme: Studi Relasi dan Transformasi Organisasi Islam Radikal di Jawa Tengah \& D.I. Yogyakarta. Diedit oleh Bonar Tigor 
Naispospos (last). Yogyakarta: Pustaka Masyarakat Setara, 2012.

Hiariej, Eric. "Aksi dan Identitas Kolektif Gerakan Islam Radikal di Indonesia." JSP, Jurnal Ilmu Sosial dan Ilmu Politik 4, no. 2 (November 2010).

K.H. Bagus Ahmadi, 1 Maret 2016. Pengasuh Pondok Pesantren MIA, Moyoketen Tulungagung.

K.H. Muh. Nurul Huda, 19 Februari 2016.

- - , 2 Maret 2016. Pengasuh Pondok Pesantren Panggung Tulungagung.

K.H. Muhson Hamdani, 27 Februari 2016. Pengasuh Pondok Pesantren Sunan Kalijaga Ngunut Tulungagung.

,--- 2 Maret 2016.

"Masyarakat Tulungagung Demo Tolak FPI." Diakses 28 Februari 2016. http://news.okezone.com.

Masyhudi Muchtar, dkk. Aswaja An-Nahdliyah, Ajaran Ahlussunnah wa Al-Jama'ah yang Berlaku di Lingkungan Nahdlatul Ulama. Surabaya: LTN, 2007.

Mubarak, M. Zaki. “Dari NII ke ISIS: Transformasi Ideologi dan Gerakan dalam Islam Radikal di Indonesia Kontemporer." Epistemê, Jurnal Pengembangan Ilmu Keislaman 10, no. 1 (Juni 2015).

Muhammad, Husein. "Memahami Sejarah Ahlus Sunnah Waljamaah Yang Toleran dan Anti Ekstrem." In Kontroversi Aswaja, Aula Perdebatan dan Reinterpretasi, diedit oleh Imam Baehaqi. Yogyakarta: LKiS, 2000.

"MUI Tuding Pemerintah Lembek Hadapi Radikalisme."

Diakses Januari 2016.

http://nasional.sindonews.com pada ...

Ni'am, Syamsun. "Pesantren: The Miniature of Moderate Islam in Indonesia." Indonesian Journal of Islam and Muslim Societies 5, no. 1 (Juni 2015). 
Nuh, Nuhrison M., ed. Peranan Pesantren dalam Mengembangkan Budaya Damai. Jakarta: Badan Litbang dan Diklat Kementerian Agama, 2010.

"Pemuda di Tengah Gerakan Radikalisme Islam dan ISIS." Diakses $28 \quad$ April 2017. www.tribratanewstulungagung.net/2015/06/ polrestulungagung-pemuda-ditengah-gerakan-radikalismeislam-dan-isis/.

"Polisi Tangkap Orang yang Diduga Anggota ISIS di Tulungagung," $28 \quad$ Februari 2016. http:// www.antaranews.com.

Qodir, Zuly. Radikalisme Agama di Indonesia. Yogyakarta: Pustaka Pelajar, 2014.

Rahardjo, M. Dawam. "Fanatisme dan Toleransi." In Berislam Secara Toleran, diedit oleh Irwan Masduqi. Bandung: Mizan, 2011.

Rokhmad, Abu. "Radikalisme Islam dan Upaya Deradikalisasi Paham Radikal." Walisongo, Jurnal Penelitian Sosial Keagamaan 20, no. 1 (n.d.).

Sholeh, Badrus. Budaya Damai dalam Komunitas Pesantren. Jakarta: LP3ES, 2007.

Suradji, Adjie. "Ancaman Teroris Generasi Baru." Kompas, 3 Februari 2016.

Tarrow, Sidney. Power in Movement: Social Movement, Collective Action and Politics. Cambridge: Cambridge University Press, 1995. 